\title{
Comparative morphometrical and biochemical-genetic investigations in wild and ranch mink (Mustela vison: Carnivora: Mammalia)
}

\author{
Dieter KRUSKA and Arnd SCHREIBER
}

\begin{abstract}
Kruska D. and Schreiber A. 1999. Comparative morphometrical and biochemical-genetic investigations in wild and ranch mink (Mustela vison: Carnivora: Mammalia). Acta
\end{abstract} Theriologica 44: 377-392.

Morphometrical and biochemical-genetic comparisons were performed between wild (Mustela vison energumenos Bangs, 1896) and ranch mink (Dark Standard strain) to investigate intraspecific differences and to characterize effects of the domestication in this species. All animals were kept under similar conditions in larger open air enclosures prior to dissection to keep modificatory influences on the measures low and comparable. In the morphometrical part of this study weights of the total body, brain, eyes, thoracal viscera, heart, abdominal viscera, liver, spleen, kidneys, adrenals, and pancreas of 82 ( 39 males, 43 females) wild and 97 ( 50 males, 47 females) ranch mink were compared using the allometrical method with the net carcas weight as the reference parameter. Only three organs were significantly smaller in size in the ranch mink group: brain, heart, and spleen. Size decreases may result from reductions of central nervous and circulatory functions in the domesticated organism. They were compared with results in other species and evaluated as a genetically linked intraspecific adaptation to the special ecological demands of domestication. Twenty five proteins encoded by products of 44 genetic loci were compared electrophoretically between 7 wild and 7 ranch mink. Except for one esterase isozyme locus all genes examined were monomorphic. The protein heterozygosity was rather low in both groups. These results were discussed in connection with certain bottleneck situations, with investigations in other species, and with the short domestication time of ranch mink.

Institut für Haustierkunde, Universität Kiel, Olshausenstr. 40, D-24118 Kiel, Germany, e-mail: dkruska@ifh.uni-kiel.de (DK); Zoologisches Institut, Universität Heidelberg, Im Neuenheimer Feld 230, D-69120 Heidelberg, Germany, e-mail: r05@ix.urz.uni-heidelberg.de (AS)

Key words: Mustela vison, domestication, morphometrics, allozymes

\section{Introduction}

The domestication of animals has led to a variety of qualitative and quantitative changes in morphology, anatomy, physiology, behaviour, and other biological features (Herre and Röhrs 1990). The diversifications due to domestication become especially clear when well established strains or races of domesticated forms are compared with offspring from the free-ranging, wild ancestor still living under natural conditions. It is a general zoological phenomenon that wild populations and derived domesticated forms belong to the same species (Herre and Röhrs 1990). Thus, from a zoological point of view, domestication effects are intraspecific in 
nature. A great deal of the changes from a wild to a domesticated animal are undoubtedly the result of artificial selection according to species- specific human breeding aims. However, there are differences between the wild progenitor and the derived domesticated form that obviously were not intended by breeding. Some of these occur in parallel among several species, and these might be especially characteristic for the domestication process in general (Kruska 1980, 1988).

Changes of biological features also occurred during the origin of species and their evolution and adaptive radiation. Convergences are known from interspecific comparisons within phylogenetic groups. In most cases these are adaptations produced by natural selection for a special ecological niche adaptation. Also these evolutionary changes must have started at the intraspecific level. Thus, in principle, character transformations due to domestication do not differ from phylogenetic changes. Domestication effects might in general serve as a general model for an understanding of the evolutionary response and plasticity of an organism (Darwin 1868).

It is further of interest to obtain information about how fast these changes may occur. It is known that keeping animals in captivity over several generations eg as is done in zoological gardens does not lead to very impressive and remarkable changes of anatomical features (Kruska 1989) although several minor preadaptations seem to occur rather quickly. On the other hand, very impressive intraspecific differences of biological features are characteristic for the so-called classical domesticated forms that live under human care for several thousand years when compared with their ancestors (Herre and Röhrs 1990). Thus, recently domesticated species are of interest for the study of domestication. Such an example is provided by ranch mink, since, in a way, they intercalate between truly domesticated forms and wild animals managed by captive breeding only. Domestication of the American mink (Mustela vison) took place approximately 120 generations ago, and today several strains or races of ranch mink (Mustela vison $\mathrm{f}$. dom.) are already established (Enders 1952, Shackelford 1949, 1984). Comparative quantitative investigations on bodily proportioning and organ weights between wild and ranch mink were reported earlier (Drescher 1975). However, this study was based on wild mink caught during starvation time in winter, and on ranch mink that lived well-nourished in small cages under human care. Some differences between both groups compared may therefore at least partly be due to different living conditions. They thus may overshadow probable genetically determined differences. The aim of this study is to compare individuals of wild and domesticated mink bred and kept under comparable conditions. Additionally, allozymes were investigated in some individuals.

\section{Material and methods}

\section{Animals}

Ten individuals of wild mink ( 3 males, 7 females) of the subspecies Mustela vison energumenos Bangs, 1896 were used as stock for a breeding colony at the Institut für Haustierkunde of the 
University of Kiel. These animals were caught in the wild of the Yukon Territory, Canada and transported to Kiel in 1988. Only these wild mink individuals were bred under human care during the years from 1989 to 1993 . They gave life to many offsprings of which altogether 82 (39 males, 43 females) were used for this study.

Ranch mink were bred from 1977 to 1981 at the Institut für Zoologie of the Veterinary University at Hannover, and from 1982 to 1988 in Kiel. Ninty-seven (50 males, 47 females) of these were used here. They are descendents of 7 individuals ( 2 males, 5 females) of a Dark Standard strain obtained from the Bundesforschungsanstalt für Kleintierzucht at Celle and the Conti-Minkfarm at Mülheim. Several individuals of following generations were used here for breeding purposes in this colony. However, no special breeding aims were followed up and direct interbreeding of parents with children or brothers with sisters was not permitted.

Ir order to keep environmental influences on the organism similar, all animals lived under comparable conditions in altogether 18 open air enclosures. These were built up with covered wire $2 \mathrm{~m}$ high and different in surface area (from about $15 \mathrm{~m}^{2}$ to $35 \mathrm{~m}^{2}$ ). They were provided with natural grourd and grass as well as bush vegetation. Each enclosure included several wooden nest boxes and a water basin. The animals were offered facilities for several activities although they were in general environmentally restricted. Only on certain occasions and for short time intervals some individuals were kept in small cages normally used on mink farms. The animals were fed daily mainly with 1-day-old chickens but occasionally fish and mice were also given. The animals lived in small family groups or as single individuals per enclosure. They were all individually known and were allowed to reach different ages (from 7 months up to 7.5 years). Those used here were adult. They were also healthy and in good condition before they were sacrificed by injection of Nembutal or Eutha under deep inaesthesia. This procedure is in accordance with the official German regulations for research on animals and the German animal welfare act.

\section{Morphological comparison}

Inmediately after death the animals were dissected and the weight of the following body parts and organs was recorded: total body (TBW), net carcass (NCW = TBW minus weight of fur, viscera, and fat), brain (BW), eyes (EW), total of thoracal viscera (TVW), heart (HW), total of abdominal viscera (AVW), liver (LW), spleen (SW), kidneys (KW), adrenals (AW), and pancreas (PW). These data served for calculations of body proportions in a group comparison of wild with ranch mink.

Hwever, organ sizes of animals are in a certain sense dependent of body size and because domesticated forms are often smaller or/and larger than their ancestral wild counterparts univariate compırisons of organ weights may lead to questionable results. Therefore, divariate allometrical analyses were performed according to the following procedure: The relationship of organ weight to body weight is characterized by the linear function $\log y=a \log x+\log b$ in a double $\log$ plot $(y-$ organ weight; $\mathrm{x}$ - body weight; $\mathrm{a}$ - slope; $\mathrm{b}$ - intercept, position). NCW was chosen being an appropriate reference measure for comparisons of wild with domesticated individuals. Calculations were thus made of the relationships of TBW as well as of body parts and organ weights to NCW. Firstly, to investigate possille sexual dimorphic differences, allometrical lines (main axis of distribution ellipses) were calculated separately for female and male wild mink. Correlations were proofed at a $99.9 \%$ significance level. The same was done for the ranch mink data. As a result no sexual dimorphism could be assured at an level of significance, and thus body proportions of female and male individuals within each group are evaluated being alike.

At a consequence, calculations were then made of intraspecific but intersexual allometrical lines for al the relationships on the total of wild mink data and the ranch mink data as well. The allomtrical lines of both groups in each relationship were then tested for differences in slope and/or position (Rempe 1962) at a $99.9 \%$ significance level. In cases of differences in intercept of a given relatinship, percentages were calculated of body part or organ size differences between wild $(=100 \%)$ and runch mink using the b-values of comparable lines. Such size differences of organs independent of body ize were further evaluated as they are mainly genetically linked changes of body proportions and organc functional capacity at a species level due to domestication. 


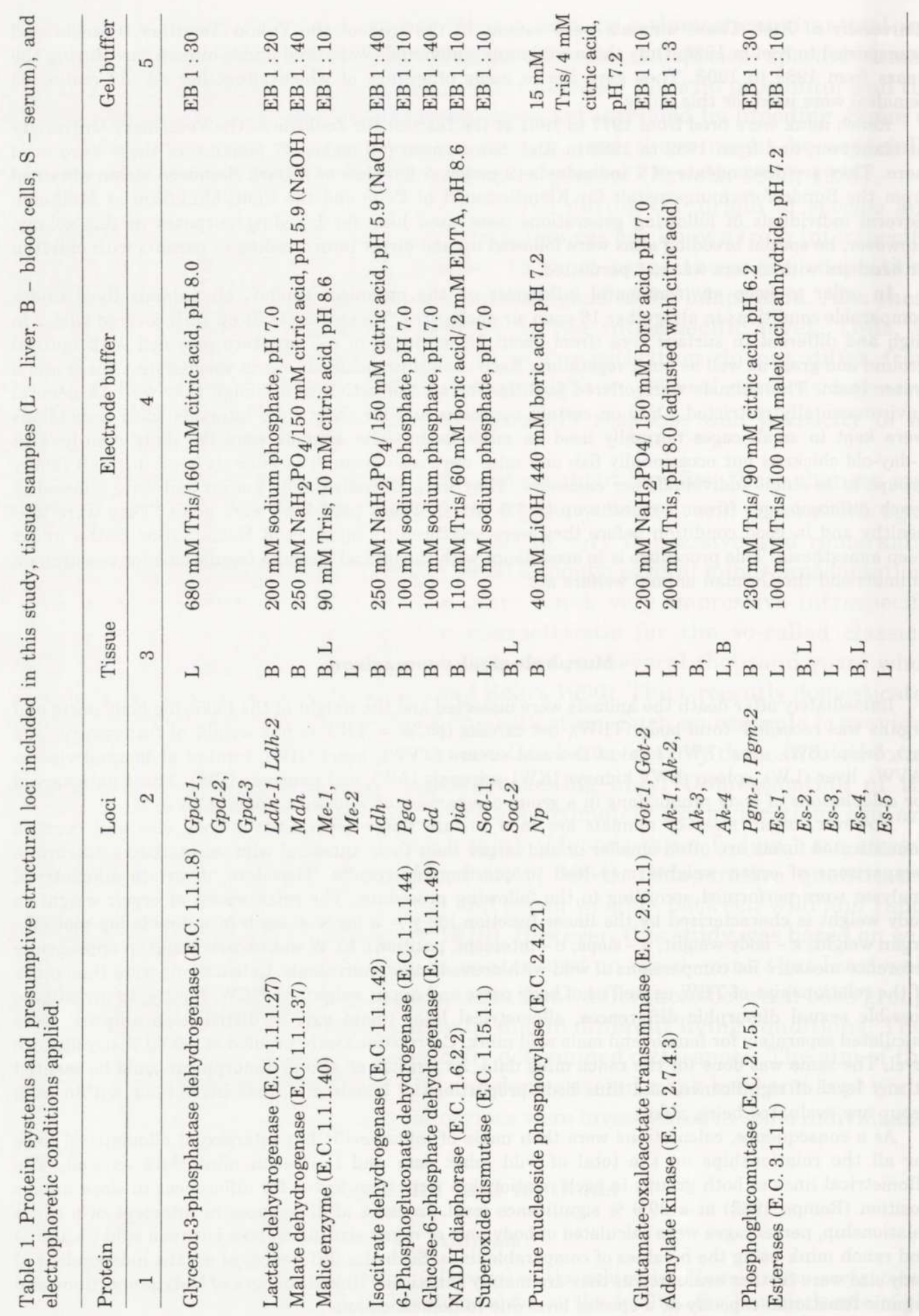




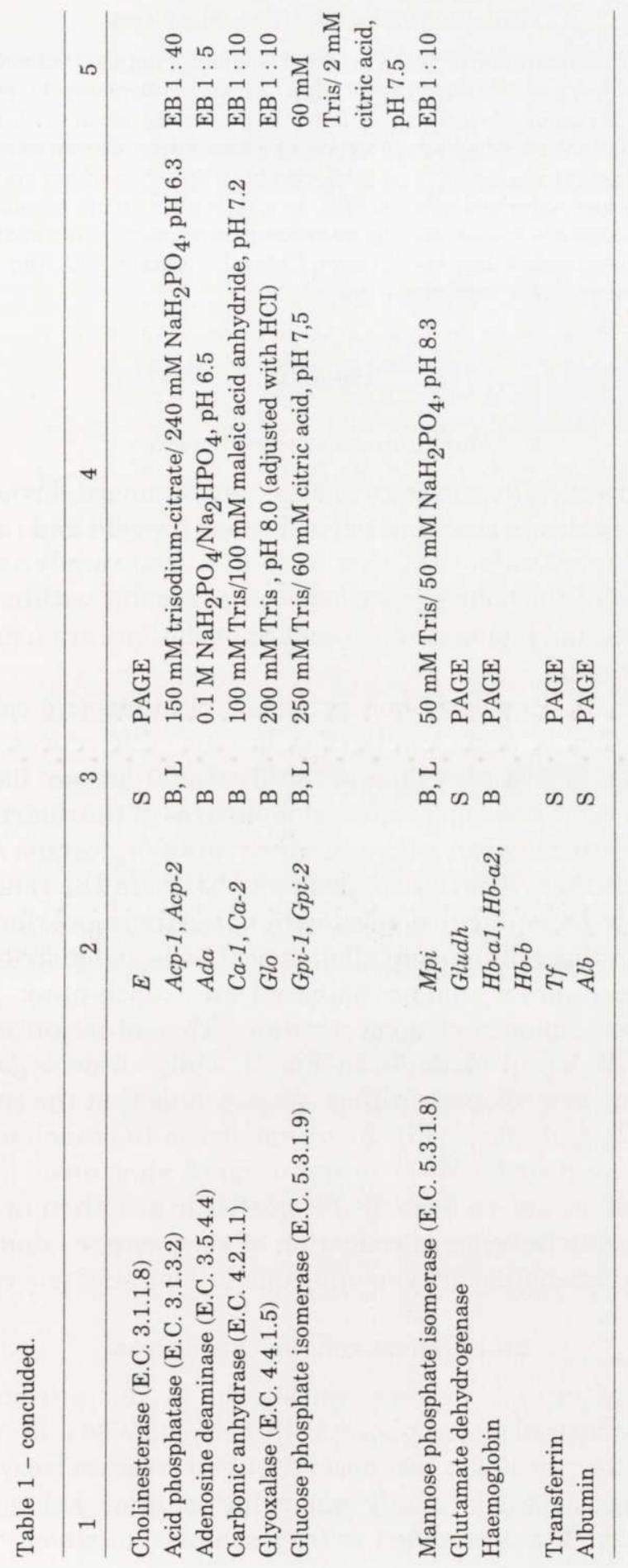




\section{Biochemical-genetic comparison}

Blood samples were taken from five of the originally imported founder individuals of the wild mink colony ( 2 males, 3 females) and from five ranch mink ( 2 males, 3 females). Liver tissue was available from two additional individuals of each population. Blood cells (B), serum (S), and liver (L) samples were stored at $-70^{\circ} \mathrm{C}$ until electrophoresis. Blood cells or tissue were disrupted by ultrasonication and applied to $1 \%$ agarose gels (LE agarose, F.M.C. Rockland, USA). Zymogram staining followed Harris and Hopkinson (1976) and Aebersold et al. (1987). In oligolocus-isozyme systems, the electromorphs representing individual loci are enumerated by proceeding from cathodic to anodic bands. Investigated protein systems and presumptive loci are listed in Table 1, together with the tissue distribution of allozymes and the electrophoretic conditions applied.

\section{Results}

\section{Morphological comparison}

Geometrical means, Min and Max values, and standard deviations of absolute body and organ weights are summarized in Table 2 for wild and ranch mink of both sexes. Here, it is interesting to note that in an univariate analysis the absolute size variability for most of the body parts is somewhat greater within the domesticated form. In both males and females, the standard deviations are usually larger in the ranch mink (Table 2).

However, divariate considerations by means of allometric calculations on the basis of NCW resulted in some similarities, but also differences between the wild and the ranch mink. Statistical values of these calculations are listed in Table 3. In each of the comparisons the slope values of main axes of the distribution ellipses do not differ significantly between wild and ranch mink $\left(a_{w}\right.$ versus $a_{t}$ values in Table 3 ). This means that there is no size dependent change in the relationships of body part or organ size to NCW due to domestication. Furthermore, for most of the body parts and organs in this relationship allometrical lines and distribution ellipses are also identical in position for wild as compared with ranch mink. This indicates no differences as a consequence of domestication. This situation is shown for liver weight versus NCW as an example in Fig. 1. Only three organs had different intercept values for their allometric lines. We conclude that the relative sizes of the brain, heart (Fig. 2), and spleen (Fig. 3) are smaller in the ranch mink than in mink from the wild. At any given NCW the brains of ranch mink on an average are $10.6 \%$, the heart $8.1 \%$, and the spleen even $28.2 \%$ smaller in size than in wild mink (Table 3 ). Thus, a genetically linked size reduction of these organs and most probably a decrease of their functional capacity in mink due to domestication can be concluded.

\section{Biochemical-genetic comparison}

Twenty-five protein systems representing the products from 44 presumptive genetic loci were compared electrophoretically between wild and ranch mink (Table 1). Polymorphism for two alleles was observed at an esterase isozyme locus, $E s$ - 1 , ie the locus encoding the least rapidly migrating isozyme among the five anodic esterases. This enzyme was confined to liver samples, in which one heterozygote, 
Table 2. Geometrical means (GM), minimum and maximum values (Min - Max), and standard deviations (SD) of absolute body and organ weights (in $g$ ) of female (f) and male (m) wild (wild) and ranch (ranch) mink.

\begin{tabular}{|c|c|c|c|c|c|c|}
\hline Body part / organ & Group & Sex & $n$ & GM & Min - Max & SD \\
\hline Net carcass NCW & $\begin{array}{l}\text { wild } \\
\text { ranch }\end{array}$ & $\begin{array}{l}\mathrm{f} \\
\mathrm{m} \\
\mathrm{f} \\
\mathrm{m}\end{array}$ & $\begin{array}{l}43 \\
39 \\
42 \\
42\end{array}$ & $\begin{array}{l}345 \\
583 \\
382 \\
580\end{array}$ & $\begin{array}{l}270-438 \\
386-731 \\
229-491 \\
326-810\end{array}$ & $\begin{array}{l}1.12 \\
1.15 \\
1.16 \\
1.23\end{array}$ \\
\hline Total body TBW & $\begin{array}{l}\text { wild } \\
\text { ranch }\end{array}$ & $\begin{array}{l}\mathrm{f} \\
\mathrm{m} \\
\mathrm{f} \\
\mathrm{m}\end{array}$ & $\begin{array}{l}43 \\
39 \\
40 \\
42\end{array}$ & $\begin{array}{r}625 \\
1041 \\
690 \\
1006\end{array}$ & $\begin{array}{l}473-858 \\
690-1410 \\
358-975 \\
505-1435\end{array}$ & $\begin{array}{l}1.16 \\
1.16 \\
1.22 \\
1.24\end{array}$ \\
\hline Brain BW & $\begin{array}{l}\text { wild } \\
\text { ranch }\end{array}$ & $\begin{array}{l}f \\
m \\
f \\
m\end{array}$ & $\begin{array}{l}43 \\
39 \\
40 \\
42\end{array}$ & $\begin{array}{r}8.14 \\
10.30 \\
7.41 \\
9.44\end{array}$ & $\begin{array}{l}7.32-9.36 \\
8.92-11.59 \\
6.60-8.49 \\
7.77-10.72\end{array}$ & $\begin{array}{l}1.06 \\
1.06 \\
1.08 \\
1.09\end{array}$ \\
\hline Eye EW & $\begin{array}{l}\text { wild } \\
\text { ranch }\end{array}$ & $\begin{array}{l}f \\
m \\
f \\
m\end{array}$ & $\begin{array}{l}41 \\
36 \\
30 \\
31\end{array}$ & $\begin{array}{l}0.43 \\
0.57 \\
0.47 \\
0.60\end{array}$ & $\begin{array}{l}0.37-0.53 \\
0.48-0.65 \\
0.39-0.76 \\
0.50-0.72\end{array}$ & $\begin{array}{l}1.09 \\
1.07 \\
1.14 \\
1.10\end{array}$ \\
\hline Thoracal viscera TVW & $\begin{array}{l}\text { wild } \\
\text { ranch }\end{array}$ & $\begin{array}{l}f \\
m \\
f \\
m\end{array}$ & $\begin{array}{l}42 \\
39 \\
40 \\
42\end{array}$ & $\begin{array}{l}22.3 \\
32.5 \\
20.5 \\
30.9\end{array}$ & $\begin{array}{l}13-33 \\
21-47 \\
12-33 \\
17-50\end{array}$ & $\begin{array}{l}1.25 \\
1.24 \\
1.28 \\
1.29\end{array}$ \\
\hline Heart HW & $\begin{array}{l}\text { wild } \\
\text { ranch }\end{array}$ & $\begin{array}{l}\mathrm{f} \\
\mathrm{m} \\
\mathrm{f} \\
\mathrm{m}\end{array}$ & $\begin{array}{l}43 \\
39 \\
40 \\
42\end{array}$ & $\begin{array}{l}4.73 \\
7.19 \\
4.69 \\
6.66\end{array}$ & $\begin{array}{l}3.30-8.17 \\
5.11-9.34 \\
3.63-6.87 \\
4.97-10.2\end{array}$ & $\begin{array}{l}1.18 \\
1.13 \\
1.14 \\
1.18\end{array}$ \\
\hline Abdominal viscera AVW & $\begin{array}{l}\text { wild } \\
\text { ranch }\end{array}$ & $\begin{array}{l}\mathrm{f} \\
\mathrm{m} \\
\mathrm{f} \\
\mathrm{m}\end{array}$ & $\begin{array}{l}43 \\
39 \\
40 \\
42\end{array}$ & $\begin{array}{l}90.9 \\
134 \\
103 \\
135\end{array}$ & $\begin{array}{l}61-166 \\
99-179 \\
53-165 \\
60-217\end{array}$ & $\begin{array}{l}1.29 \\
1.17 \\
1.35 \\
1.34\end{array}$ \\
\hline Liver LW & $\begin{array}{l}\text { wild } \\
\text { ranch }\end{array}$ & $\begin{array}{l}\mathrm{f} \\
\mathrm{m} \\
\mathrm{f} \\
\mathrm{m}\end{array}$ & $\begin{array}{l}43 \\
39 \\
40 \\
42\end{array}$ & $\begin{array}{l}25.0 \\
36.3 \\
26.2 \\
36.5\end{array}$ & $\begin{array}{l}17.4-36.9 \\
28.2-49.8 \\
14.8-39.8 \\
19.3-72.0\end{array}$ & $\begin{array}{l}1.21 \\
1.15 \\
1.26 \\
1.32\end{array}$ \\
\hline Spleen SW & $\begin{array}{l}\text { wild } \\
\text { ranch }\end{array}$ & $\begin{array}{l}\mathrm{f} \\
\mathrm{m} \\
\mathrm{f} \\
\mathrm{m}\end{array}$ & $\begin{array}{l}42 \\
38 \\
40 \\
42\end{array}$ & $\begin{array}{l}2.58 \\
3.32 \\
2.07 \\
2.59\end{array}$ & $\begin{array}{l}1.33-5.56 \\
1.83-6.88 \\
0.86-6.18 \\
0.92-5.00\end{array}$ & $\begin{array}{l}1.41 \\
1.29 \\
1.51 \\
1.44\end{array}$ \\
\hline Kidney KW & $\begin{array}{l}\text { wild } \\
\text { ranch }\end{array}$ & $\begin{array}{l}\mathrm{f} \\
\mathrm{m} \\
\mathrm{f} \\
\mathrm{m}\end{array}$ & $\begin{array}{l}42 \\
39 \\
40 \\
41\end{array}$ & $\begin{array}{l}3.95 \\
6.33 \\
4.40 \\
6.03\end{array}$ & $\begin{array}{l}3.05-5.25 \\
4.66-8.62 \\
3.11-5.73 \\
4.09-8.38\end{array}$ & $\begin{array}{l}1.16 \\
1.17 \\
1.16 \\
1.19\end{array}$ \\
\hline Adrenals AW & $\begin{array}{l}\text { wild } \\
\text { ranch }\end{array}$ & $\begin{array}{l}\mathrm{f} \\
\mathrm{m} \\
\mathrm{f} \\
\mathrm{m}\end{array}$ & $\begin{array}{l}40 \\
39 \\
39 \\
42\end{array}$ & $\begin{array}{l}0.05 \\
0.07 \\
0.06 \\
0.08\end{array}$ & $\begin{array}{l}0.02-0.13 \\
0.04-0.14 \\
0.02-0.15 \\
0.04-0.17\end{array}$ & $\begin{array}{l}1.41 \\
1.40 \\
1.48 \\
1.37\end{array}$ \\
\hline Pancreas PW & $\begin{array}{l}\text { wild } \\
\text { ranch }\end{array}$ & $\begin{array}{l}\mathrm{f} \\
\mathrm{m} \\
\mathrm{f} \\
\mathrm{m}\end{array}$ & $\begin{array}{l}40 \\
38 \\
22 \\
16\end{array}$ & $\begin{array}{l}2.08 \\
3.07 \\
2.33 \\
2.68\end{array}$ & $\begin{array}{l}0.99-3.33 \\
1.09-4.65 \\
1.19-3.27 \\
1.21-4.34\end{array}$ & $\begin{array}{l}1.28 \\
1.30 \\
1.25 \\
1.41\end{array}$ \\
\hline
\end{tabular}


Table 3. Statistical values for the intraspecific allometrical relationship of total body weight, body part weights and organ weights (in g) to net carcass weight (in g) in wild and ranch mink $n$ - number, GM geometrical mean, SD - standard deviation, $\mathrm{a}_{\mathrm{w}}$ - slope of allometrical line within each group, $r$ correlation, $\mathrm{a}_{\mathrm{t}}$ - slope of allometrical line of total data sets, D - percentage size difference of ranch compared to wild mink $(100 \%)$ at identical NCW.

\begin{tabular}{llllllllll}
\hline Body part / organ & Group & $n$ & GM & SD & $\mathrm{a}_{\mathrm{w}}$ & $r$ & $\mathrm{a}_{\mathrm{t}}$ & $r$ & $\mathrm{D}(\%)$ \\
\hline Total body TBW & wild & 82 & 797 & 1.34 & 1.01 & 0.97 & 1.02 & 0.96 & 0 \\
& ranch & 82 & 837 & 1.33 & 1.02 & 0.94 & & & \\
Brain BW & wild & 82 & 9.11 & 1.14 & 0.42 & 0.93 & 0.44 & 0.85 & -10.6 \\
& ranch & 82 & 8.38 & 1.16 & 0.46 & 0.78 & & & \\
Eye EW & wild & 77 & 0.49 & 1.17 & 0.49 & 0.85 & 0.51 & 0.80 & 0 \\
Thoracal viscera TVW & ranch & 61 & 0.53 & 1.18 & 0.54 & 0.73 & & & \\
& wild & 81 & 26.8 & 1.33 & 0.98 & 0.70 & 1.11 & 0.71 & 0 \\
Heart HW & ranch & 82 & 25.3 & 1.38 & 1.24 & 0.72 & & & \\
Abdominal viscera AVW & wild & 82 & 5.77 & 1.29 & 0.86 & 0.90 & 0.84 & 0.88 & -8.1 \\
& ranch & 82 & 5.61 & 1.26 & 0.82 & 0.85 & & & \\
Liver LW & wild & 82 & 110 & 1.33 & 0.98 & 0.69 & 1.12 & 0.69 & 0 \\
& ranch & 82 & 118 & 1.38 & 1.27 & 0.69 & & & \\
Spleen SW & wild & 82 & 29.8 & 1.29 & 0.83 & 0.79 & 0.98 & 0.76 & 0 \\
& ranch & 82 & 31.0 & 1.36 & 1.15 & 0.74 & & & \\
Kidney KW & wild & 80 & 2.91 & 1.39 & 1.25 & 0.51 & 1.64 & 0.50 & -28.2 \\
& ranch & 82 & 2.32 & 1.49 & 0.73 & 0.50 & & & \\
Adrenals AW & wild & 81 & 4.96 & 1.32 & 0.96 & 0.90 & 0.88 & 0.87 & 0 \\
Pancreas PW & ranch & 81 & 5.16 & 1.25 & 0.78 & 0.83 & & & \\
& wild & 79 & 0.06 & 1.45 & 1.97 & 0.33 & 2.21 & 0.34 & 0
\end{tabular}

Es-1 70/100, was observed, combining the common allele with a slower variant reaching $70 \%$ of the anodic mobility of the former. With only two liver samples available per breeding colony, reliable allele frequencies or degrees of heterozygosity cannot be estimated. All other loci produced monomorphic band patterns, with the possible exception of unspecified, Coomassie-stained plasma proteins intercalating between albumin and transferrin, which also appeared to be variable. However, we are unaware of the locus identity of these "post-albumins" and hesitate to interpret their diversity without examining larger pedigrees. Mink had not been starved before blood- sampling, and sera were heavily loaded with lipids, which may affect the electrophoretic mobility of plasma proteins.

The limited number of samples available prohibits the exact quantitation of allozyme differentiation between our breeding lines of ranch and wild mink, and of heterozygosity values. The sample of altogether 44 loci, however, indicates a rather low electrophoretic heterozygosity for either breeding colony. 


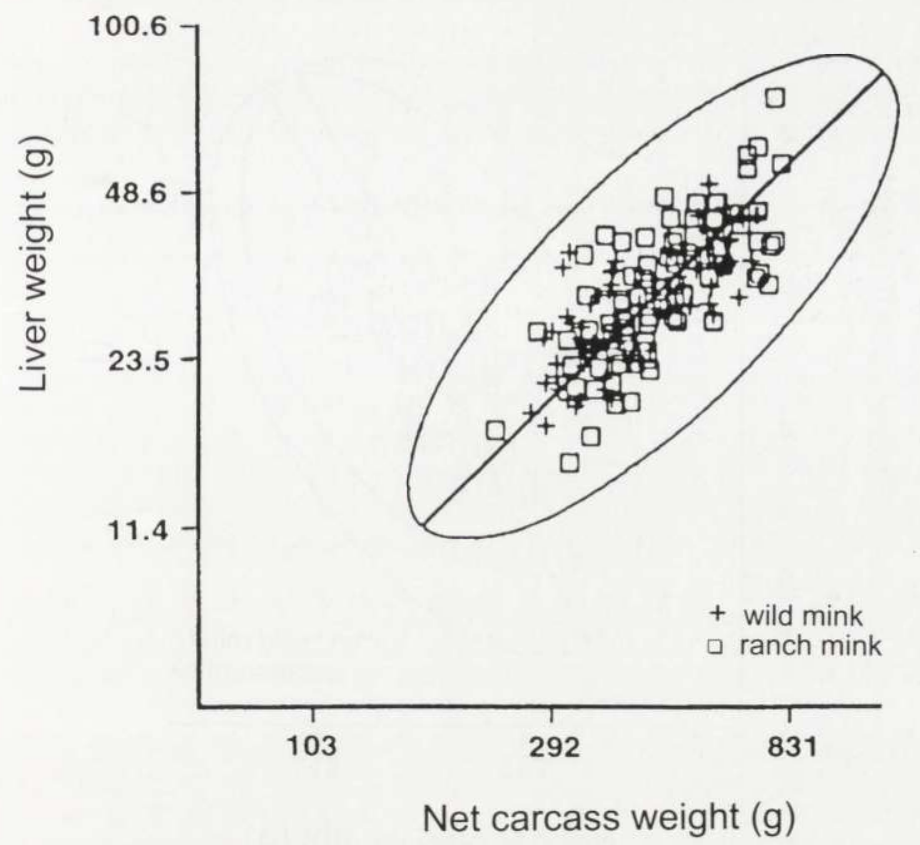

Fig. 1. Double log. plot of data for liver weight (LW) and net carcass weight (NCW), common distribution ellipsis and allometrical line for wild and ranch mink. There is no difference in this relationship between both groups.

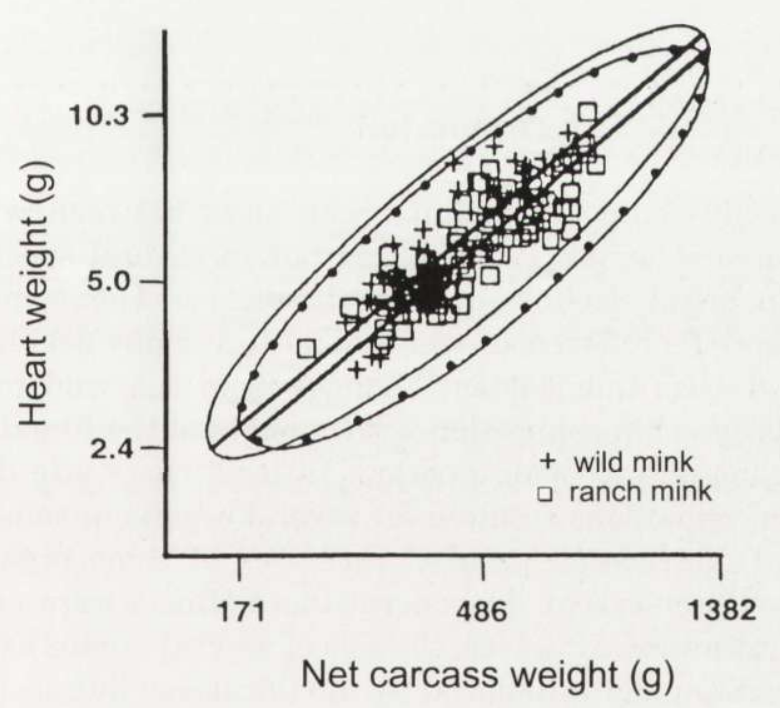

Fig. 2. Double log. plot of data for heart weight (HW) and net carcass weight (NCW), distribution ellipses (pointed for the domesticated form) and allometrical lines for wild and ranch mink. The allometrical line for ranch mink runs parallel to, but below that of wild mink indicating that ranch mink have by $8.1 \%$ lower heart weight at any body weight. 


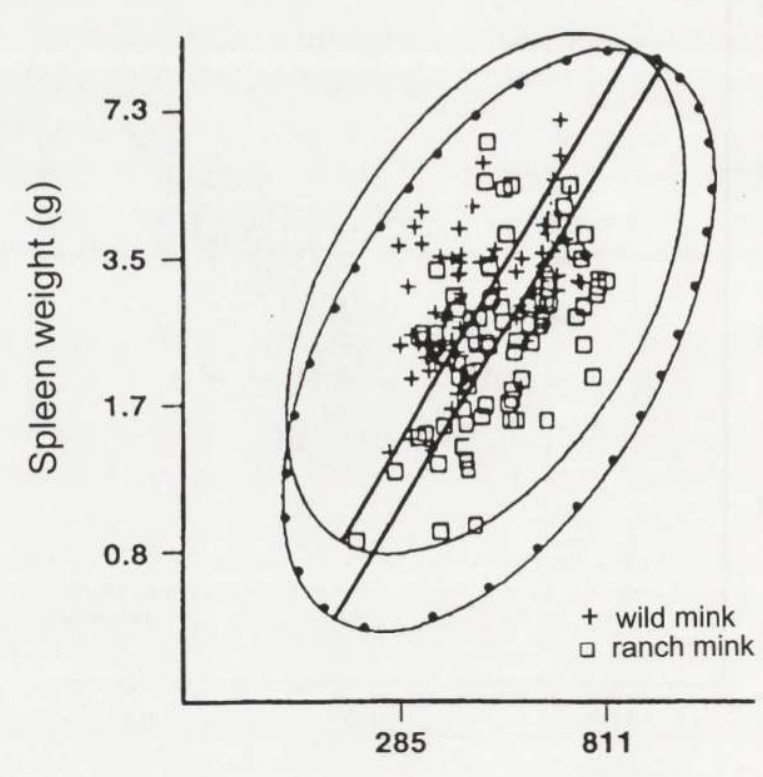

Net carcass weight $(g)$

Fig. 3. Double log. plot of data for spleen weight (SW) and net carcass weight (NCW), distribution ellipses (pointed for the domesticated form) and allometrical lines for wild and ranch mink. The allometrical line for ranch mink runs parallel to, but below that of wild mink indicating that ranch mink have by $28.2 \%$ lower spleen weight at any body weight.

\section{Discussion}

Comparisons of body composition and organ sizes between wild ancestral forms and domesticated relatives were worked out in several species using the allometrical method in organ size to body size relations (see Herre and Röhrs 1990 for review). Species-specific differences were found to various degrees for several organs indicating body size independent changes from the wild to the derived forms. These were discussed in connection with changes of the functional capacity of the respective organs due to domestication. In most cases size decreases and accordingly functional reductions resulted for several organs in some species as a consequence of the domestication process. Increases of some organs were also documented but to a lesser extent. In general these effects were assumed to be mainly genetically determined. However, the size of several organs as well as those of total bodies are additionally influenced by modifications due to nutrition and general life style. These factors are undoubtedly different between a wild natural life and that under domestication. Thus, the above mentioned results very often may present a certain mixture of modificatory with genetically linked influence. For these reasons, the present study based on wild and ranch mink kept under 
comparable conditions in larger enclosures, which implies a certain environmental impoverishment for the wild and an enrichment for the ranch mink that normally very restrictively are kept in small cages. For example modifications may become evident from the following: In an allometric comparison of the total body versus net carcass weight caged ranch mink from a mink farm clearly had higher total body weights at any given net carcass weight than wild mink that were raised in enclosures (Kruska 1996). On the contrary, no differences were found in the present study concerning this relation between wild and ranch mink from enclosures. Thus, the results obtained here most probably express genetically linked effects due to domestication. They seem not comparable with those on wild and ranch mink of Drescher (1975), and wild polecat (Mustela putorius) and derived ferret (M. putorius f. furo) by Espenkötter (1982). These studies based on free-ranging wild and well-nourished domesticated animals.

However, although a greater variability in morphometric data occurred for ranch mink the present study revealed only little change of the bodily proportions of mink due to domestication probably for reasons of the rather short-timed event of only about 120 generations and / or for reasons of minor selective pressure on ranch mink concerning breeding aims. None of the measured organs were targeted by breeding. Therefore, the results may especially enlighten unconscious effects characteristic for domestication in general.

In this connection the body size independent weights of heart, spleen, and brain of ranch mink can be discussed. These organs clearly have decreased due to domestication most probably not only in size but also in functional capacity. The mass of heart muscle for example corresponds directly with the pumping function of this circulatory organ (Hesse 1921). Earlier studies on laboratory rats (Kirch and Nürnberger 1939) and albinotic laboratory mice (Class 1961) trained for swimming revealed an increase of heart weight compared with caged individuals. Similar modificatory effects resulted for albinotic mice kept in larger enclosures compared with caged individuals (Zehner 1967). However, the results on mink kept under identical conditions may point to a genetic selection for less locomotory active individuals adapted for an environmentally restricted life in smaller cages. The results on the spleen may point into the same direction. In mammals 2 types of spleen evolved. A primitive "defence" or "metabolism" spleen poorly built up by trabeculae and smooth muscle cells but rich in lymphoid tissue can be contrasted by the "storage" spleen rich in trabeculae and smooth muscle cells but poor in lymphoid tissue. Mustelids like other carnivores have spleens of the latter type formed by a monolayered capsule with large reticulum parts of red pulp (up to about $80 \%$ ) which represent storage-sites for erythrocytes (Hartwig and Hartwig 1985). These spleens show stable weight ratios with the heart and have a powerful effect on the circulation (Tischendorf 1969, 1985). It can therefore be assumed that the size decrease of ranch mink spleen is mainly caused by a decrease of the red pulp which additionally may point to less circulatory functions in the domesticated organism. 
The results on brain size are in accordance with those in other species confirming a general size decrease due to domestication (Kruska 1980, 1987, 1988). There are, however, uncertainties concerning the degree of size decrease from wild to ranch mink. Allometrical comparisons of brain size to net carcass weight between wild mink kept in enclosures and ranch mink reared on a farm in small cages revealed $20 \%$ size decrease for the domesticated form (Kruska 1996), whereas in this study using the same relation a value of only $11 \%$ size decrease resulted. The ranch mink kept in larger enclosures thus have larger brains than those from cages. It therefore could be argued that the enriched environmental conditions for the mink in this study may lead to an increase of brain size as was stated for especially trained rats (Bennett et al. 1964, Rosenzweig and Bennett 1972). However, brain size is mainly genetically determined. This conclusion came from interbreeding of wolf with poodle (Weidemann 1970) or donkey with horse (Kruska 1973). Modificatory effects on brain size and skull cavity if so ever occurring seem of little importance (Bedi and Bhide 1988). At least, feralisation of domestic stock and its establishment in natural habitats must be evaluated as an enrichment of environment. But this process does not lead to an enlargement of brain size again either modificatorily nor genetically. Eg dingos from Australia are descendants of early domestic dogs that for several thousand years live under wildlife conditions. They still have brains equally in size with modern dog breeds (Schultz 1969). A comparable result is valid for shorter times of feralisation as was found for pigs from the Galapagos Islands (Kruska and Röhrs 1974) and donkeys from South America (Kruska 1973). Their brain sizes fall into the normal variety of individuals from husbandry. Thus, the domestication effect on brain size seems irreversible in general and thus also in mink by manipulating the environment. Therefore, the brain size differences of ranch mink from cages and enclosures seem not explainable in this way. On the other hand, the population of ranch mink raised in enclosures derived from only few individuals that were obtained from two farms and a control of the total data set revealed that these individuals as well as those from first generation accidentally had brain sizes within the normal variation of ranch mink but clearly larger than on average. Therefore, the greater brain size of the ranch mink population dealt with here most probably must be attributed to a founder effect in a genetically determined bottleneck situation. Altogether, mink individuals obviously are favoured in domestication with slightly less sizes and functions of the central nervous system and circulatory organs.

Conclusions from our biochemical-genetic results are limited because of the small sample sizes. However, a fairly extensive locus sample (Gorman and Renzi 1979) suggests that mink exhibit low allozyme heterozygosity! Previous authors have stressed that carnivores, and mustelids in particular, displayed rather limited allozyme variability. Electrophoretic monomorphism was reported by Simonsen (1982) for common and abundant mustelid species like stoats (Mustela erminea), weasels (M. nivalis), polecats (M. putorius), beech and pine martens (Martes foina, M. martes) and badgers (Meles meles), and by Kilpatrick et al. (1986) for the rare 
black-footed ferret (Mustela nigripes). However, nine of ten investigated species of Felidae, the carnivoran family on which the most detailed allozyme data are available, were characterized by a notable biochemical-genetic variability (Newman et al. 1985, Randi and Ragni 1991). Hartl et al. (1988) doubted that mustelids, or even carnivores as an order, are genetically less variable than other mammals, and described fairly elevated heterozygosities for weasels and stoats from Austrian populations, with somewhat less marked variability for small series of badgers, polecats, and beech martens. These authors inferred that previous findings of zero-polymorphism resulted from too narrow locus samples, and from the biased selection of loci displaying less variability than average. We are not aware of a multilocus electrophoretic analysis of wild mink, and the geographic partitioning remains unknown across the vast Nearctic range which harbours 15 subspecies (Hall 1981). Broader species samples, including those Alaskan and Canadian subspecies involved in the creation of domestic stock (Castle and Moore 1946, Shackelford 1949), need to be studied before the low heterozygosity of our wild mink colony can be generalized for the species. No multilocus electrophoretic analyses were done of ranch mink either, although individual systems have been investigated in some strains and colour mutants: Richter and Hartung (1970) found monomorphic haemoglobins, albumins, transferrin, and haptoglobin in Standard, Platinum, and Saphir strains, and Mullakondov et al. (1986) encountered polymorphic peptidases in Standard, Hedlund, and Black Cross strains. Simonsen et al. (1992) described plasma esterase variability, and demonstrated certain genetic differences between domesticated strains, which were explained by founder effects or selection during pure-breeding of mutants with desired fur quality or other commercially relevant performance. Allotypes of serum proteins (Belyaev $e t$ al. 1984), and DNA-microsatellite polymorphism (O'Connell et al. 1996) complement the still limited knowledge on the molecular variation in ranch mink which is too scanty to derive firm estimations of genomic variability.

We compared individuals of one subspecies as an approximate model for ancestral undomesticated stock with individuals of a Standard domesticated strain. Both lineages have been isolated for at least 120 generations. This period is unsufficiently short for genetic changes which are reflected by qualitative allozyme analysis. Moreover, the very low electrophoretic variability encountered in our sample series of 10 mink precludes the recognition of possible frequency differences of polymorphic alleles which could be expected as a result of the domestication process. Thus, allozymes might not constitute a suitable approach to describe the population evolution of mink during domestication. Using three different DNA-microsatellite loci, Belliveau et al. (1996) investigated wild mink from New Brunswick (most probably Mustela vison vison) and three ranch mink strains. The wild mink showed the lowest genetic variability, but wild and ranch mink were separated by the highest average genetic distance. As far as "older" domestications are concerned, Peterka and Hartl (1992) compared allozymes of wild and domestic rabbits, and Randi and Ragni (1991) wild cats with domestic strains. Both studies 
revealed measurable genetic distances between the wild and the domesticated populations of species which, however, displayed higher allozyme variability than mink seem to do, and which therefore permit the comparison of allele frequencies.

Allozymes should be studied in larger population samples, but the increased morphometric variability of ranch mink demonstrated by our data does not appear to correlate with increased electrophoretic protein variation.

Acknowledgements: We very much thank Mrs. A. Ingwersen from the Institut für Haustierkunde for excellent and competent technical work concerning computer use and ms. writing.

\section{References}

Aebersold P. B., Winans G. A., Teel D. J., Milner G. B. and Utter F. M. 1987. Manual for starch gel electrophoresis: A method for the detection of genetic variation. NOAA Technical Report NMFS 61.

Bedi K. S. and Bhide P. G. 1988. Effects of environmental diversity on brain morphology. Early Human Development 17: 107-143.

Belliveau A. M., O Connell M., Farid A. H. and Wright J. M. 1996. Assessment of genetic variability and genetic distance between wild and ranched American mink using microsatellites. [In: Progress in fur animal science. A. Frindt and M. Brzozowski, eds]. Polish Society for Animal Production, Warsaw: 77-80.

Belyaev D. K., Baranov O. K., Yermolaev V. I. and Savina M. A. 1984. Genetics and evolution of the mink Lpm system. Genetika 20: 128-139.

Bennett E. L., Diamond M. C., Krech D. and Rosenzweig M. R. 1964. Chemical and anatomical plasticity of brain. Science 146: 610-619.

Castle W. E. and Moore L. 1946. Mutations of mink under domestication. Journal of Heredity 37: $137-145$

Class I. 1961. Der Einfluß vermehrter körperlicher Tätigkeit auf die Organgewichte von Albinomäusen. Zeitschrift für Anatomie und Entwicklungsgeschichte 122: 251-265.

Darwin C. 1868. Das Variieren der Tiere und Pflanzen im Zustande der Domestikation. Transl. by V. Carus 1906. Stuttgart: E. Schweizerbart'sche Verlagsbuchhandlung.

Drescher H.-E. 1975. Der Einfluß der Domestikation auf die Körper- und Organproportionierung des Nerzes. Zeitschrift für Tierzüchtung und Züchtungsbiologie 92: 272-281.

Enders R. K. 1952. Reproduction in the mink (Mustela vison). Proceedings of the American Philosophical Society 96: 691-755.

Espenkötter E. 1982. Vergleichende quantitative Untersuchungen an Iltissen und Frettchen. Dissertation thesis, Veterinary Highschool, Hannover.

Gorman G. C. and Renzi J. Jr 1979. Genetic distance and heterozygosity estimates in electrophoretic studies: effects of sample size. Copeia 2: 242-249.

Hall E. R. 1981. The mammals of North America. 2. ed. Vol. 2. John Wiley and Sons, New York, Toronto: 1000-1004.

Harris H. and Hopkinson D. A. 1976. Handbook of enzyme electrophoresis in human genetics. American Elsevier, New York.

Hartl G. B., Willing R., Grillitsch M. and Klansek E. 1988. Biochemical variation in Mustelidae: Are carnivores genetically less variable than other mammals? Zoologischer Anzeiger 221: 81-90.

Hartwig H. and Hartwig H. G. 1985. Structural characteristics of the mammalian spleen indicating storage and release of red blood cells. Aspects of evolutionary and environmental demands. Experientia 41: 159-163.

Herre W. and Röhrs M. 1990. Haustiere - zoologisch gesehen. 2. ed. G. Fischer, Stuttgart, New York: 1-412. 
Hesse R. 1921. Das Herzgewicht der Wirbeltiere. Zoologisches Jahrbuch, Abteilung für allgemeine Zioologie 38: 243-364.

Kilpatrick C. W., Forrest S. C. and Clark T. W. 1986. Estimating genetic variation in the black-footed ferret - a first attempt. Great Basin Natural Memoirs 8: 145-149.

Kirch E. and Nürnberger W. 1939. Entwicklungsgang und Rückbildung der sportlichen Herzhypertrophie inn Tierversuch. Archiv für Kreislaufforschung 4: 1-18.

Kruskka D. 1973. Cerebralisation, Hirnevolution und domestikationsbedingte Hirngrößenänderungen innerhalb der Ordnung Perissodactyla Owen, 1848 und ein Vergleich mit der Ordnung Artiodactyla Owen, 1848. Zeitschrift für zoologische Systematik und Evolutionsforschung 11: 81-103.

Kruska D. 1980. Domestikationsbedingte Hirngrößenänderungen bei Säugetieren. Zeitschrift für zoologische Systematik und Evolutionsforschung 8: 161-195.

Kruska D. 1987. How fast can total brain size change in mammals? Journal für Hirnforschung 28 : 59-70.

Kruska D. 1988. Mammalian domestication and its effect on brain structure and behavior. [In: Intelligence and Evolutionary Biology. H. J. Jerison and I. Jerison, eds]. Springer, Berlin, Heidelberg: 211-250.

Kruska D. 1989. Gehirnveränderungen bei Säugetieren als Folge von Gefangenschaftshaltung? [In: Die Illusion der Arche Noah. E. Schneider, H. Oelke and H. Gross, eds]. Echo Verlag, Wiesbaden: 87-105.

Kruska D. 1996. The effect of domestication on brain size and composition in the mink (Mustela vison). Journal of Zoology, London 239: 645-661.

Kruska D. and Röhrs M. 1974. Comparative-quantitative investigations on brains of feral pigs from the Galapagos-Islands and of European domestic pigs. Zeitschrift für Anatomie und Entwicklungsgeschichte 144: 61-73.

Mullakondov M. R., Gradov A. A., Zakijan S. M., Rubtsov N. B. and Serov O. L. 1986. Peptidases A, B, $\mathrm{C}, \mathrm{D}$ and $\mathrm{S}$ in the American mink: polymorphism and chromosome localization. Theoretical Applied Genetics 73: 272-277.

Newman A., Bush M., Wildt D. E., Van Dam D., Frankenhuis T., Simmons L., Philiips L. and O’Brien S. J. 1985. Biochemical genetic variation in eight endangered or threatened felid species. Journal of Mammalogy 66: 256-267.

O'Connell M., Wright J. M. and Farid A. 1996. Development of PCR primers for nine polymorphic American mink Mustela vison microsatellite loci. Molecular Ecology 5: 311-312.

Peterka M. and Hartl G. B. 1992. Biochemical genetic variation and differentiation in wild and domestic rabbits. Zeitschrift für zoologische Systematik und Evolutionsforschung 30: 129-141.

Randi E. and Ragni B. 1991. Genetic variability and biochemical systematics of domestic and wild cat populations (Felis silvestris: Felidae). Journal of Mammalogy 72: 79-88.

Rempe U. 1962. Über einige statistische Hilfsmittel moderner zoologisch- systematischer Untersuchungen. Zoologischer Anzeiger 169: 93-140.

Richter H. and Hartung J. 1970. Vergleichende elektrophoretische Untersuchungen über Hämoglobin und verschiedene Plasmaproteine von einigen Musteliden. Archiv für experimentelle Veterinärmedizin 24: 985-995.

Rosenzweig M. R. and Bennett E. L. 1972. Cerebral changes in rats exposed individually to an enriched environment. Journal of comparative physiological Psychology 80: 304-313.

Schultz W. 1969. Zur Kenntnis des Hallstromhundes (Canis hallstromi Throughton, 1757). Zoologischer Anzeiger 183: 47-72.

Shackelford R. M. 1949. Origin of the American ranch-bred mink. American Fur Breeder 22: 12-14.

Shackelford R. M. 1984. American mink. [In: Evolution of domesticated animals. I. L. Mason, ed]. Longman, London, New York: 229-233.

Simonsen V. 1982. Electrophoretic variation in large mammals II. Hereditas 96: 299-305.

Simonsen V., Damgaard B. M., Larsen B. and Lohi O. 1992. Genetic polymorphism of esterase in plasma of American mink (Mustela vison L.). Animal Genetics 23: 553-555. 
Tischendorf F. 1969. Die Milz. [In: Handbuch der mikroskopischen Anatomie des Menschen. Vol. 6. W. Bargmann, ed]. Springer, Berlin, New York: 1-968.

Tischendorf F. 1985. On the evolution of the spleen. Experientia 41: 145-152.

Weidemann W. 1970. Die Beziehungen von Hirngewicht und Körpergewicht bei Wölfen und Pudeln sowie deren Kreuzungsgeneration $\mathrm{N}_{1}$ und $\mathrm{N}_{2}$. Zeitschrift für Säugetierkunde 35: 238-247.

Zehner I. 1967. Über den Einfluß veränderter Umwelt (Freigehege) auf das Herzgewicht der Albinomaus. Zoologischer Anzeiger 178: 1-18.

Received 4 May 1998, accepted 26 March 1999. 